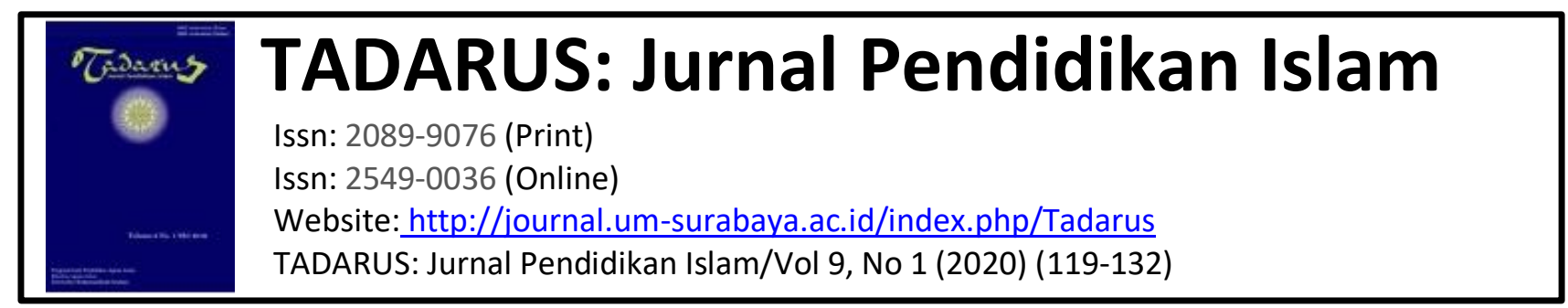

\title{
TEORI PERKEMBANGAN SOSIAL ANAK DAN PENGARUHNYA BAGI PENDIDIKAN
}

\author{
Zainal Arifin \\ zainal0920@yahoo.co.id \\ Program Pascasarjana Prodi Pendidikan Islam, UMSurabaya
}

\begin{abstract}
Abstrak
Tujuan dari penelitian ini adalah untuk menggali tentang teori perkembangan sosial anak dan faktor-faktor yang mempengaruhi perkembangan sosial anak. Penelitian ini adalah penelitian kualitatif dengan jenis penelitian pustaka (library research), dan teknik analisis datanya menggunakan induktif dan deduktif. Temuan penelitian ini dapat disimpulkan: pertama, terdapat tiga teori perkembangan sosial anak, yaitu: teori nativisme, empirisme, dan konvergensi. Teori nativisme mengatakan bahwa manusia akan berkembang seperti apa sangat tergantung dari pembawaan. Teori empirisme menyatakan bahwa bayi ketika lahir ibarat kertas yang masih putih bersih, dan akan tumbuh dan berkembang, seorang anak sangat tergantung pengaruh dari luar yang datang. Teori konvergensi menyatakan bahwa pertumbuhan dan perkembangan manusia tergantung pada dua faktor: yaitu bakat atau pembawaan dan lingkungan atau sekolah. Teori konvergensi mengakui bahwa manusia lahir telah membawa bakat atau potensi-potensi dasar yang dapat dikembangkan. Proses pengembangan sangat tergantung pada lingkungan masyarakat dan sekolah. Kedua, Proses perkembangan sosial anak atau sebagai makhluk sosial yang berkepribadian dipengaruhi oleh banyak faktor, baik faktor internal (yang berasal dari dalam diri anak) maupun faktor eksternal (yang berasal dari luar diri anak). Ada lima faktor yang menjadi dasar perkembangan kepribadian anak, yaitu sifat dasar, lingkungan prenatal, perbedaan individual, lingkungan dan motivasi.
\end{abstract}

Kata Kunci: Teori, Sosial, Anak

\section{Pendahuluan}

Manusia tanpa manusia lain pasti mati, ${ }^{1}$ merupakan falsafah hidup manusia sebagai makhluk sosial. Sebagai makhluk individu, ia memiliki karakter yang unik berbeda satu dengan yang lain, bahkan kalaupun merupakan hasil cloning, dengan pikiran dan kehendaknya yang bebas. Dan sebagai makhluk sosial ia membutuhkan manusia lain, membutuhkan sebuah kelompok -dalam bentuknya yang minimal, yang mengakui keberadaannya, dan dalam bentuknya yang maksimal- kelompok di mana

\footnotetext{
${ }^{1}$ Soerjono Soekanto, Sosiologi suatu Pengantar, (Jakarta: Raja Grafindo Persada, 2013), 114
} 
dia dapat bergantung kepadanya. Sebagai makhluk sosial, manusia tidak dapat hidup sendiri. Manusia membutuhkan kebersamaan dalam kehidupannya. Semua itu adalah dalam rangka saling memberi dan saling mengambil manfaat. Orang kaya tidak dapat hidup tanpa orang miskin yang menjadi pembantunya, pegawainya, sopirnya, dan seterusnya. Demikian pula orang miskin tidak dapat hidup tanpa orang kaya yang mempekerjakan dan mengupahnya. ${ }^{2}$ Allah SWT berfirman yang artinya: "Apakah mereka yang membagi-bagi rahmat Rabbmu?Kami telah menentukan antara mereka penghidupan mereka dalam kehidupan dunia, dan Kami telah meninggikan sebagian mereka atas sebagian yang lain beberapa derajat, agar sebagian mereka dapat mempergunakan sebagian yang lain. Dan rahmat Rabbmu lebih baik dari apa yang mereka kumpulkan."(Az-Zukhruf: 32).

Aristoteles mengkategorikan manusia ke dalam "Zoon Politicon" yang berarti manusia adalah makhluk yang ingin selalu bergaul dan berkumpul. Jadi manusia adalah makhluk yang bermasyarakat. Oleh karena sifat suka bergaul dan bermasyarakat itulah manusia dikenal sebagai makhluk sosial. Ia mengatakan bahwa manusia adalah makhluk sosial bukan bermaksud untuk menegaskan ide tentang kewajiban manusia untuk bersosialisasi dengan sesamanya, melainkan ide tentang makhluk sosial terutama bermaksud menunjuk langsung pada kesempurnaan identitas dan jati diri manusia.

Menurut pandangan Islam, manusia secara etimologi disebut juga insan yang dalam bahasa Arabnya berasal dari akar kata nasiya yang berarti lupa. Dan jika dilihat dari akar kata al-uns maka kata insan berarti jinak. Dari kedua akar kata tersebut kata insan dipakai untuk menyebut manusia, karena manusia memiliki sifat lupa dan jinak. Dalam arti, manusia selalu menyesuaikan diri dengan keadaan yang baru di sekitarnya. Keberadaan manusia sangat nyata sekali berbeda dengan makhluk yang lainnya. Seperti dalam kenyataannya manusia adalah makhluk yang berjalan di atas dua kaki dan memiliki kemampuan untuk berfikir. Sedangkan berfikir itu sendiri merupakan sifat dasar dari manusia yang menentukan hakekat manusia itu sendiri dan membedakannya dengan makhluk lainnya.

Manusia juga memiliki karya yang dihasilkannya sehingga berbeda dengan makhluk yang lain. Hasil karya manusia itu dapat dilihat dalam setting sejarah dan setting psikologis, geografis, situasi emosional dan intelektual yang melatarbelakangi

2 Zaenal Abidin Ahmad, Konsep Negara Bermoral menurut al-Ghozali, (Jakarta: Bulan Bintang, 2015), 29 
hasil karyanya. Dari hasil karya yang dibuat manusia tersebut, menjadikan ia sebagai makhluk yang menciptakan sejarah.

Pengertian sosial menurut para ahli adalah Hubungan individu dalam sebuah komunitas dan bagaimana cara mereka menjalin hubungan antar sesama dalam berbagai kegiatan bersama dan hubungan ini merupakan inti dari sebuah interaksi di antara mereka di lingkungan masing-masing dan tidak terikat oleh sebuah pola tertentu.

Karena sosial merupakan cara manusia berhubungan dengan sesama dalam berbagai kegiatan, maka seiring dengan perkembangan budaya manusia, sifat sosial juga mengalami perkembangan seiring dengan perkembangan pranata-pranata yang timbul berdasarkan tujuan atau kegiatan yang telah disepakati bersama oleh mereka. ${ }^{3}$

\section{Metode Penelitian}

Jenis penelitian ini adalah penelitian pustaka (library research), yaitu penelitian yang obyek utamanya adalah buku-buku atau sumber kepustakaan lain. Maksudnya, data dicari dan ditemukan melalui kajian pustaka dari buku-buku yang relevan dengan pembahasan. Penelitian ini adalah penelitian kualitatif dengan jenis penelitian pustaka (library research). Penelitian kualitatif ini menggunakan prosedur kegiatan dan teknik penyajian finalnya secara deskriptif. ${ }^{4}$ Maksudnya, tujuan dari penelitian ini adalah untuk mendapatkan gambaran yang jelas tentang perkembangan sosial anak.

\section{Hasil dan Analisis Penelitian}

\section{Teori Perkembangan Sosial Anak}

Istilah perkembangan sangat jarang ditemukan dalam kamus sosiologi. Istilah yang biasa digunakan dalam bidang sosiologi adalah evolusi (evolution), kemajuan (progress) dan perubahan (change). Sedangkan perkembangan (development) sering dipakai dalam bidang pendidikan dan psikologi, sosiologi pendidikan adalah gabungan dua disiplin ilmu yang berbeda, kiranya sah-sah saja untuk menggunakan istilah perkembangan (development) yang mempunyai makna sama dengan istilah perubahan (change) dan evolusi (evolution). Yang dimaksud dengan teori perkembangan sosial anak di sini adalah teori yang dipakai dalam bidang filsafat dan sosiologi tentang perkembangan manusia. Jika dalam psikologi pendidikan dibahas

\footnotetext{
${ }^{3}$ M. Fahim Tharaba dan Moh. Padil, Sosiologi Pendidikan Islam, (Malang: Dream Litera, 2015), 109

${ }^{4}$ Lexy J Moleong, Metodologi Penelitian Kualitatif, (Bandung : Remaja Rosda Karya, 2014), 6.
} 
tentang perkembangan manusia dari sisi psikologis, maka dalam sosiologi pendidikan dibahas tentang perkembangan manusia dilihat dari segi sosiologi.

Dalam dunia pendidikan tidak bisa dipisahkan dengan disiplin ilmu lain. Pendidikan memerlukan psikologi pendidikan dan sosiologi pendidikan yang berasal dari disiplin ilmu psikologi dan ilmu sosiologi. Kedua disiplin ilmu ini dibutuhkan dalam pengembangan pendidikan untuk mencari jalan dalam menentukan dan memberikan arah terhadap efek sekolah bagi tingkah laku individu. Kedua ilmu tersebut merupakan alat untuk merealisasikan tujuan pendidikan. Dalam rangka untuk merealisasikan tujuan pendidikan, kedua ilmu ini mempunyai cara yang berbeda. Psikologi pendidikan adalah suatu ilmu yang berhubungan dengan teknik bagi pembentukan kebiasaan-kebiasaan baru dalam diri anak melalui pendekatanpendekatan hukum dari ilmu jiwa praktis untuk mencari, mengumpulkan dan mengevaluasi pengalaman-pengalaman tentang belajar. Sedangkan sosiologi pendidikan berhubungan dengan masalah implikasi sosiologi, seperti pembuatan kurikulum, organisasi kelas, dan metode mengajar. Sekolah dalam kenyataannya adalah sebagai lembaga social. Adapun teori perkembangan sosial anak adalah sebagai berikut:

a. Teori Nativisme

Teori nativisme dipelopori oleh Schopenhover (1788-1860) yang mengatakan bahwa manusia akan berkembang seperti apa sangat tergantung dari pembawaan. Jika pembawaan pandai akan menjadi manusia yang pintar dan jika pembawaannya bodoh, maka akan menjadi bodoh. Perkembangan manusia bukan dipengaruhi oleh orang lain, lingkungan, budaya, dan termasuk pendidikan. Perkembangan sosial manusia telah ada bersama pembawaan sejak lahir. Teori nativisme menafikan pengaruh interaksi individu dengan lingkungannya. Lingkungan tidak berarti apa-apa dalam perkembangan manusia, apa yang dikerjakan apa yang diharapkan dan apa yang dipikirkan merupakan kecakapan yang dibawa sejak lahir. Proses kehidupan manusia tergantung dengan apa yang dibawa sejak lahir, tetapi nativisme tidak menjelaskan bagaimana seseorang lahir dengan membawa potensi, apakah potensi itu mempunyai hubungan sangat erat dengan kondisi orang tua atau tidak, selama ini tidak pernah ada penjelasan. Namun dalam beberapa penelitian menyimpulkan bahwa anak sangat 
dipengaruhi oleh keadaan orang tua, baik keadaan fisik, psikis, maupun sosial ekonominya. $^{5}$

b. Teori Empirisme

Teori empirisme dipelopori oleh John Locke (1632-1704) yang menyatakan bahwa bayi ketika lahir ibarat kertas yang masih putih bersih, dan akan tumbuh dan berkembang, seorang anak sangat tergantung pengaruh dari luar yang datang. Jadi perkembangan anak sepenuhnya tergantung pada faktor lingkungan, sedangkan pembawaan tidak ada pengaruhnya. Dasar yang dipakai aliran empirisme adalah bahwa bayi pada saat dilahirkan dalam keadaan putih bersih seperti kertas putih yang belum ditulisi, sehingga akan ditulisi apa tergantung pada penulisnya. Hal ini berarti baik dan buruknya anak tergantung pada baik dan buruknya pendidikan yang diterimanya. Menurut Jean Jaquees Rausseau (1712-1778) bahwa manusia itu pada dasarnya baik sejak ia dilahirkan. Jadi kalau ada manusia yang jahat bukan karena benihnya, tetapi dikembangkan setelah ia lahir, yakni setelah ia hidup di masyarakat dan setelah terpengaruh oleh lingkungan serta kebudayaan.

\section{c. Teori Konvergensi}

Teori ini dipelopori oleh William Stern yang merupakan perpaduan antara teori empirisme dan teori nativisme. Teori konvergensi menyatakan bahwa pertumbuhan dan perkembangan manusia tergantung pada dua faktor: yaitu bakat atau pembawaan dan lingkungan atau sekolah. Teori konvergensi mengakui bahwa manusia lahir telah membawa bakat atau potensi-potensi dasar yang dapat dikembangkan. Proses pengembangan sangat tergantung pada lingkungan masyarakat dan sekolah. Misalnya seseorang yang lahir dengan membawa potensi cerdas akan bisa menjadi cerdas apabila dikembangkan, baik melalui pendidikan masyarakat maupun pendidikan sekolah (formal). Akan tetapi potensi cerdas tersebut akan tetap ada pada diri manusia dan tidak berkembang, apabila tidak bergaul dan hidup dengan masyarakat dan sekolah. ${ }^{6}$

2. Faktor-Faktor yang Mempengaruhi Perkembangan Sosial Anak

Pertanyaan yang menarik dalam masalah ini adalah mengapa para sosiolog ikut memusingkan diri dengan soal kepribadian? Bukankah soal tersebut lebih sesuai menjadi bidang para psikolog? Jawabannya adalah dikembalikan kepada penyelidikan para sosiolog tentang pola-pola tingkah laku sosial. Tingkah laku sosial perlu dicari

\footnotetext{
${ }^{5}$ Abu Ahmadi, Sosiologi Pendidikan, (Surabaya: PT. Bina Ilmu, 2016), 109.

${ }^{6}$ M. Fahim Tharaba dan Moh. Padil, Sosiologi Pendidikan Islam, (Malang: Dream Litera, 2015), 112
} 
penyebabnya, yaitu terbentuknya kepribadian individu. Hal ini merupakan hubungan yang tak terpisahkan antara ilmu sosiologi dengan ilmu-ilmu yang lain, terutama psikologi sosial. Psikologi sosial adalah studi sosial ilmiah tentang proses mental manusia sebagai makhluk sosial. Obyek psikologi sosial adalah tingkah laku manusia di masyarakat sebagai ungkapan proses mental kejiwaan yang meliputi keamanan, minat reaksi, emosional dan kecerdasan. Sikap mental seseorang, reaksi emosional, kemauan dan perhatiannya merupakan dorongan dan gejala kejiwaan. Tetapi semua itu tidak harus semata-mata menunjukkan ungkapan proses mentalnya, melainkan juga dipengaruhi oleh lingkungan (alam, sosial, budaya).

Faktor-faktor yang menyebabkan terjadinya tingkah laku manusia adalah: (1) Struktur sosio-kultural, yaitu tingkah pola tingkah laku ideal yang diharapkan; (2) Faktor situasi, yaitu semua kondisi fisik dan sosial dimana berada dan diterapkan sesuai dengan sistem sosial; (3) Faktor kepribadian, yaitu semua faktor psikologis dan biologis yang mempengaruhi tingkah laku para pelaku secara perseorangan.

Dilihat dari aspek-aspek perkembangan sosial anak tampak dalam dua aspek, yaitu: (1) Aspek biologis, makan, minum, dan perlindungan yang telah dapat mengubah bayi menjadi manusia yang dewasa jasmaniyah; (2) Aspek personal sosial, yaitu pengalaman dan pengaruh manusia lain telah mengubah anak menjadi pribadi sosial dan warga masyarakat yang bertanggungjawab. ${ }^{7}$ Dari kedua aspek perkembangan sosial anak tersebut, pembahasan ini akan difokuskan pada faktorfaktor yang menyebabkan perkembangan sosial anak dalam aspek personal sosial saja.

Proses perkembangan sosial anak atau sebagai makhluk sosial yang berkepribadian dipengaruhi oleh banyak faktor, baik faktor internal (yang berasal dari dalam diri anak) maupun faktor eksternal (yang berasal dari luar diri anak). Menurut FG Robins ada lima faktor yang menjadi dasar perkembangan kepribadian anak, yaitu sifat dasar, lingkungan pre-natal, perbedaan individual, lingkungan dan motivasi. ${ }^{8}$

a. Sifat Dasar

Sifat dasar merupakan keseluruhan potensi yang diwarisi oleh seseorang dari ayah dan ibunya. Sifat dasar ini terbentuk pada saat konsepsi, yaitu momen bertemunya sel jantan (ayah) dan sel betina (ibu) pada saat pembuahan. Menurut

\footnotetext{
${ }^{7}$ Vembriarto, Sosiologi Pendidikan, (Yogyakarta: Gunung Agung, 2010), 24.

${ }^{8}$ Abu Ahmadi, Sosiologi Pendidikan, (Surabaya: PT. Bina Ilmu, 2016), 183.
} 
Hasan Langgulung, ${ }^{9}$ pada saat peniupan roh pada diri manusia, maka pada saat itu pula manusia (dalam bentuk yang sempurna) mempunyai Sebagian sifat ketuhanan. Sebagian sifat ketuhanan inilah yang dalam perkembangan manusia disebut sifat dasar/fitrah manusia. Potensi bawaan yang dimiliki oleh manusia yang paling penting antara lain: (a) Sifat dasar beragama; (b) Sifat dasar berakal budi; (c) Kebersihan dan kesucian; (d) Bermoral dan berakhlak; (e) Kebenaran; (f) Keadilan; (g) Persamaan dan kesatuan; (h) Individual; (i) Sosial; (j) Seksual; (k) Ekonomi; (1) Politik; dan (m) Seni.

b. Lingkungan Pre-natal

Fase prenatal (sebelum lahir), mulai masa konsepsi sampai proses kelahiran, lebih kurang 280 hari. $^{10}$ Yang dimaksud dengan lingkungan pre-natal adalah lingkungan dalam kandungan ibu. Dalam lingkungan pre-natal ini individu mendapatkan pengaruh secara tidak langsung dari ibu. Tindakan orang tua yang berpengaruh terhadap anak dalam kandungan ada yang bersifat religious, seperti dalam Islam banyak beribadah kepada Allah, banyak membaca al-Qur'an, banyak berdoa dan berbudi pekerti yang baik. Ada juga yang bersifat ilmiah, seperti memberi makanan yang halal dan bergizi, menjaga kesehatan dan kebersihan, menciptakan kedamaian dan ketenangan dalam rumah tangga, mempelajari ilmu-ilmu umum dan agama dalam rangka mendidik anak kelak setelah lahir dan sebagainya.

c. Perbedaan Individual

Perbedaan individual merupakan salah satu faktor yang mempengaruhi perkembangan sosial anak sejak anak dilahirkan, akan tumbuh dan berkembang sebagai individu yang unik, yang berbeda dengan individu lainnya. Perbedaan individu ini terletak pada:

1) Perbedaan fisik, seperti bentuk badan, warna kulit, rambut dan sebagainya.

2) Perbedaan psikologis, seperti IQ, emosional, mental, motivasi dan sebagainya.

3) Peranan faktor perbedaan ini menyangkal faham determinisme kultur.

Menurut faham ini kepribadian manusia itu dibentuk oleh kebudayaan masyarakatnya. Dalam kenyataan menunjukkan bahwa meskipun individu itu hidup dalam masyarakat dipengaruhi oleh kebudayaan, namun dia tetap merupakan pribadi yang bersifat unik.

\footnotetext{
${ }^{9}$ Hasan Langgulung, Manusia dan Pendidikan, (Jakarta: Pustaka al-Husna, 2006), 5

${ }^{10}$ Asrori, Psikologi Pendidikan Pendekatan Multidisipliner, (Purwokerto: Pena Persada, 2020), 37
} 


\section{d. Lingkungan}

Yang dimaksud dengan lingkungan di sini adalah kondisi di luar individu yang mempengaruhi perkembangan sosial anak. Lingkungan dapat dibedakan menjadi: (1) Lingkungan alam, yaitu tanah, iklim, flora dan fauna di sekitar individu; (2) Kebudayaan, yaitu cara hidup masyarakat dimana tempat individu hidup. Kebudayaan mempunyai aspek material, seperti rumah, perlengkapan hidup, hasil teknologi, dan sebagainya dan aspek non material, seperti nilai-nilai, pandangan hidup, adat istiadat, norma dan sebagainya; (3) Manusia dan masyarakat di luar individu. Di antara ketiga lingkunan ini yang bersentuhan langsung dengan anak dalam proses pendidikan adalah tipe ketiga. Lingkungan alam dan kebudayaan akan bermanfaat sebesarbesarnya jika digerakkan oleh manusia dan masyarakat, karena pada hakekatnya alam dan kebudayaan adalah pasif tanpa ada mobilisasi dari manusia dan masyarakat.

e. Motivasi

Motivasi merupakan akar kata dari bahasa Latin movore, yang berarti gerak atau dorongan untuk bergerak. Motivasi dalam Bahasa Indonesia, berasal dari kata motif yang berarti daya upaya yang mendorong seseorang melakukan sesuatu. Istilah motivasi berasal dari kata motif yang dapat diartikan sebagai kekuatan yang terdapat dalam diri individu, yang menyebabkan individu tersebut bertindak atau berbuat. ${ }^{11}$ Motivasi adalah kekuatan diri dalam individu yang menggerakkan individu untuk berbuat. Motivasi dibedakan antara dorongan dan kebutuhan.

Dorongan adalah keadaan ketidakseimbangan dalam diri individu karena pengaruh dalam dan dari luar individu yang mengarahkan perbuatan individu dalam rangka mencapai keseimbangan Kembali atau adaptasi. Dalam diri manusia terdapat dorongan makan, minum, menghindarkan diri dari bahaya, bekerja dan sebagainya. Sedangkan kebutuhan adalah dorongan yang telah ditentukan secara personal sosial dan kultur. Kebutuhan manusia yang terpenting adalah: (a) Kebutuhan untuk bersama orang lain; (b) Kebutuhan untuk berprestasi; (c) Kebutuhan bebas dari rasa takut; (d) Kebutuhan bebas dari rasa bersalah; (e) Kebutuhan untuk turut serta dalam mengambil keputusan mengenai persoalan-persoalan yang menyangkut dirinya; (f) Kebutuhan akan kepastian ekonomi, dan lain sebagainya.

\footnotetext{
${ }^{11}$ Asrori, Psikologi Pendidikan Pendekatan Multidisipliner, 54
} 


\section{Proses Perkembangan Sosial Anak}

Perkembangan sosial anak dapat melalui dua acara, yaitu proses belajar sosial (process of learning) atau sosialisasi dan proses pembentukan kesetiaan sosial (formation of social loyalities).

a. Proses Belajar Sosial (Process of Learning)

Proses belajar sosial dapat ditemukan dalam sosiologi dengan istilah "sosialisasi". Belajar sosial berarti belajar memahami dan mengerti tentang prilaku dan Tindakan masyarakat melalui interaksi sosial. Oleh karena itu yang dibahas dalam process of learning di sini adalah sosialisasi yang mempunyai arti yang sama dengan belajar. Definisi sosialisasi menurut Thomas Ford adalah proses belajar individu untuk bertingkah laku sesuai dengan standar yang terdapat dalam kebudayaan masyarakat.

Konsep dasar sosialisasi berasal dari ilmu biologi yang disebut adaptasi yang artinya penyesuaian diri. Adaptasi dijadikan dasar oleh teori evolusi Darwin. Menurut teori evolusi hanya organisme (fisik) yang berhasil menyesuaikan diri dengan lingkungannya sajalah yang dapat tetap hidup. Penekanan adaptasi adalah segi fisik, bukan dari segi tingkah laku. Dalam ilmu psikologi penyesuaian diri disebut dengan adjustment yang mencakup masalah-masalah kebiasaan, perangai, ide-ide, sikap dan nilai-nilai sosialisasi menurut sosiologi adalah proses yang membantu individu melalui belajar dan menyesuaikan secara menyeluruh, baik diri tentang cara-cara kehidupan maupun cara-cara berpikir kelompok agar dapat berperan dan berfungsi dalam kelompoknya.

Tingkah laku manusia dapat dipahamkan sebagai reaksi dari tuntutan atau tekanan dari lingkungannya. Tuntutan itu ada yang bersifat fisik, seperti di daerah yang dingin, manusia harus berpakaian yang tebal untuk memenuhi tuntutan lingkungan iklim, untuk menghindarkan diri dari hujan dan terik matahari, serta dinginnya udara malam, manusia membangun rumah yang kokoh.

Selain tingkah laku manusia sebagai reaksi dari tuntutan lingkungan fisik, manusia juga menghadapi tuntutan sosial masyarakat. Pada seorang yang masih bayi atau anak-anak, orang tua memberi tuntutan terhadapnya agar dapat menerima nilainilai dan memiliki pola-pola tingkah laku yang baik. Di sekolah dia mendapat tuntutan dari kepala sekolah, guru dan teman-temannya untuk dapat bertingkah laku yang dapat diterima oleh mereka. Dan setelah dewasa ia tidak terlepas pula dari tuntutan orang lain untuk bertingkah laku yang dapat diterima oleh mereka. 
Gambaran dari berbagai tututan di atas, baik yang bersifat tuntutan lingkungan fisik maupun tuntutan lingkungan sosial, dialami oleh setiap orang dalam hidup bermasyarakat. Jika belum dapat memenuhi tuntutan fisik, maka dia dapat dikatakan belum menyesuaikan diri dengan lingkungannya. Cara penyesuaian diri seperti ini disebut adaptasi. Jika dapat memenuhi tuntutan lingkungan sosial, maka dia dikatakan dapat menyesuaikan diri dengan lingkungannya. Cara penyesuaian diri seperti ini dinamakan adjustment. Jika dapat memenuhi tuntutan lingkungan fisik dan tuntutan lingkungan sosial, yakni kedua model tuntutan itu dapat dipenuhi, maka dia dikatakan dapat menyesuaikan diri. Cara penyesuaian diri seperti ini disebut sosialisasi. Maka sosialisasi adalah suatu proses dimana kepribadian individu dibentuk melalui transmisi (pemindahan) budaya terhadap individu tersebut.

Tuntutan atau tekanan terhadap individu dalam konsep sosialisasi ada yang bersifat internal dan eksternal. Tuntutan internal adalah tuntutan yang berupa dorongan atau kebutuhan yang timbul dari dalam, baik yang bersifat fisik, maupun sosial, seperti kebutuhan makan, minum, seks, penghargaan sosial, persahabatan, cinta, perhatian, kasih sayang, dan sebagainya. Sedangkan tuntutan eksternal adalah tuntutan yang datang dari luar diri individu, seperti keadaan iklim, cuaca, lingkungan alam, individu lain dan masyarakat.

Teori yang dominan dalam membahas sosialisasi adalah teori fungsionalisme struktural Talcott Parson. Dia berpendapat bahwa realitas sebagai suatu sistem sosial, dimana bagian-bagiannya berkaitan dengan keseluruhannya dan dijelaskan berdasarkan fungsi sistem bagi keseluruhan. Semua Tindakan harus diarahkan kepada tujuan dan memperhatikan tujuan orang lain. Semua Tindakan diarahkan pada lima dilema (pattern variables), yaitu:

1) Affectivity versus affaective neutrality (afektivitas dan netralitas afektif), yaitu memandang Tindakan kita sebagai tujuan diri sendiri atau bagian dari rencana yang lebih luas.

2) Spesivity versus diffuseness (kekhususan dan kebenaran), yaitu memandang Tindakan individu yang lebih spesifik seperti pelayan toko atau memandang yang lebih luas, seperti sahabat karib.

3) Universalisme versus partikularisme.

4) Self orientation versus collectivity.

5) Achievement versus ascription (prestasi dan bawaan). 
Kelima dilema Talcott Parson di atas berorientasi pada nilai yang dihadapkan pada tiga masalah umum. Menurut Kluckhohn, ada tiga masalah umum yang berkaitan dengan dilemma Parson.

1) Orientasi kodrat manusia yang pada dasarnya jahat, tetapi dapat diubah menjadi baik, atau manusia pada dasrnya baik, tetapi dapat berubah menjadi jahat.

2) Orientasi alam, ada yang melihat pekerjaan alam di luar kontrol manusia dan ada yang memandang pekerjaan alam di bawah kontrol manusia.

3) Orientasi waktu, ada yang menekankan pada masa lampau, masa sekarang dan masa yang akan datang. Seperti orang yang akan memperoleh pekerjaan baik, harus terus belajar.

Hal ini menekankan pada masa depan, sehingga mereka tidak melihat latar belakang orang tua yang misalnya sebagai petani, atau tidak melihat masa sekarang yang belum mempunyai pekerjaan. Pendidikan dilihat dan diyakini mempunyai harapan untuk merubah nasib mereka, sehingga mereka berkeyakinan jika belajar terus, maka akan mendapatkan pekerjaan yang lebih baik.

Dasar utama sosialisasi adalah interaksi. Pengertian tentang interaksi sosial berguna dalam memperhatikan dan mempelajari berbagai masalah masyarakat, karena interaksi merupakan syarat utama terjadinya aktivitas-aktivitas sosial. Dengan kata lain interaksi sosial adalah kunci dari semua kehidupan sosial, karena tanpa interaksi sosial tidak mungkin ada kehidupan Bersama. Pengertian interaksi sosial menurut $\mathrm{H}$ Bonner adalah suatu hubungan antara dua atau lebih individu manusia, dimana kelakuan individu yang satu mempengaruhi, mengubah atau memperbaiki kelakuan individu yang lain, atau sebaliknya. ${ }^{12}$ Menurut Abu Ahmadi, interaksi sosial adalah pengaruh timbal balik antara individu dengan golongan dalam usaha mereka untuk memecahkan persoalan yang dihadapinya dan dalam usaha untuk mencapai tujuan. ${ }^{13}$

Dari beberapa definisi tersebut dapat difahamkan bahwa interaksi sosial terjadi karena ada dua individua tau lebih yang menjalin hubungan dan saling mempengaruhi dengan tujuan untuk memecahkan masalah atau untuk mencapai tujuan. Unsur-unsur pokok dalam interaksi sosial mencakup:

1) Adanya hubungan

2) Hubungan tersebut dilakukan oleh dua orang atau lebih

3) Interaksi dilakukan untuk memecahkan masalah atau mencapai tujuan.

\footnotetext{
${ }^{12}$ Karl Veger, Pengantar Sosiologi, (Jakarta: Grafindo, 2017), 63.

${ }^{13}$ Abu Ahmadi, Sosiologi Pendidikan, (Surabaya: PT. Bina Ilmu, 2016), 115
} 
Terjadinya interaksi sosial disebabkan dua hal, pertama adanya kontak sosial dan kedua adanya komunikasi. Kontak sosial dapat berlangsung dalam tiga bentuk, yaitu:

1) Antara orang per orang, seperti anak kecil mempelajari kebiasaan-kebiasaan dalam keluarga.

2) Antara orang per-orang dengan kelompok manusia, seperti apabila manusia merasakan bahwa tindakannya berlawanan dengan norma-norma masyarakat.

3) Antara satu kelompok dengan kelompok lainnya, seperti antara dua partai politik mengadakan kerja sama untuk mengalahkan partai politik lainnya dalam pemilihan umum.

Dilihat dari realitas terjadinya kontak ini, maka kontak dapat terjadi secara langsung, seperti bertatap muka, berjabat tangan, saling senyum, saling menyapa dan memberi isyarat. Kontak seperti ini disebut dengan kontak primer. Kontak sosial juga bisa terjadi dengan suatu perantara (tidak bertemu langsung), seperti perantara orang ketiga, alat kontak dan sebagainya. Kontak seperti ini disebut dengan kontak sekunder. Sebab yang lain terjadinya kontak sosial adalah adanya komunikasi. Arti komunikasi adalah seseorang memberikan penafsiran pada perilaku orang lain, perasaan-perasaan apa yang ingin disampaikan oleh orang tersebut. Orang yang bersangkutan kemudian memberikan reaksi terhadap perasaan yang ingin disampaikan oleh orang lain tersebut. Seperti seorang gadis menerima seikat bunga, dia akan memandang dan mencium bunga tersebut. Tetapi ada perasaan dalam diri gadis tersebut siapa yang mengirim bunga tersebut, apa yang menyebabkan dia mengirim bunga tersebut. Apa bunga tersebut dikirim untuk kado ulang tahun, atau untuk memenuhi suatu janji untuk mengucapkan selamat tinggal atau tanda cinta kasih dan sebagainya. Apabila gadis belum bisa menjawab pertanyaan-pertanyaan tersebut, maka ia tidak pernah tahu mengenai apa yang dikatakan dan selama itu juga belum terjadi proses komunikasi.

Berdasarkan pengertian dan sebab-sebab terjadinya interaksi di atas, maka dapat dikelompokkan macam-macam interaksi sosial sesuai dengan sudut pandangnya. Dilihat dari sudut subyeknya, interaksi bisa terjadi: (1) interaksi antar orang perorang; (2) interaksi antar orang dengan kelompoknya; (3) interaksi antar kelompok. Dilihat dari sisi caranya, ada yang dinamakan interaksi langsung dan tidak langsung. Dilihat dari segi bentuknya, Soerjono Soekanto membagi interaksi asosiatif dan 
interaksi disosiatif, dan dilihat dari segi sifatnya ada interaksi positif dan interaksi negatif. ${ }^{14}$

b. Pembentukan Kesetiaan Sosial (Formation of Social Loyalities)

Perkembangan kesetiaan sosial ini muncul berkat kesadaran individu terhadap kehidupan di tengah-tengah masyarakat. Masyarakat sumber kesetiaan bagi anggotanya. Sebab-sebab munculnya kesetiaan sosial di antaranya adalah partisipasi sosial, komunikasi dan kerja sama, individu dalam kehidupan kelompok. Anak kecl yang hadir di tengah-tengah kehidupan masyarakat secara spontan diterima sebagai anggota baru. Sebagai anggota baru, anak belum mengetahui pola dan sistem perilaku orang yang ada di sekelilingnya. Seperti anak yang baru bisa berjalan, setiap anggota masyarakat menyapa, menggandeng dan ikut membantu berjalan anak. Respon anak adalah kemesraan dan afektif (kepuasan) sehingga berjumpa lagi dengan orang etrsebut si anak langsung tersenyum dan bergerak mendekatinya.

Dengan demikian perkembangan kesetiaan sosial mengikuti pola sebagai berikut: Kerjasama menimbulkan kepuasan dan dari kepuasan menimbulkan kesetiaan sosial. Bentuk kesetiaan sosial berkembang menjadi semakin komplek kepada kelompok yang makin besar. Kesetiaan sosial dimulai dari keluarga, teman sebaya dan sekolah. Biasanya kelompok ini disebut dengan kelompok primer, di mana setiap anggota kelompok dapat berinteraksi secara langsung dan face to face. Kemudian kesetiaan sosial berkembang seiring dengan perkembangan kedewasaan seseorang, semakin dewasa seseorang semakin berkembang kesetiaan sosialnya kepada kelompok pekerjaan, kelompok agama, perkumpulan (organisasi), baik kemasyarakatan maupun bangsa. Perkembangan yang lebih luas dan besar ini disebut lingkungan sekunder, dimana seluruh anggota kelompok mencerminkan seorang individu yang komplek. ${ }^{15}$

\section{Kesimpulan}

Temuan penelitian ini dapat disimpulkan: pertama, terdapat tiga teori perkembangan sosial anak, yaitu: teori nativisme, empirisme, dan konvergensi. Teori nativisme mengatakan bahwa manusia akan berkembang seperti apa sangat tergantung dari pembawaan. Teori empirisme menyatakan bahwa bayi ketika lahir ibarat kertas yang masih putih bersih, dan akan tumbuh dan berkembang, seorang

\footnotetext{
${ }^{14}$ Soerjono Soekanto, Sosiologi suatu Pengantar, (Jakarta: Raja Grafindo Persada, 2013), 72

${ }^{15}$ M. Fahim Tharaba dan Moh. Padil, Sosiologi Pendidikan Islam, (Malang: Dream Litera, 2015), 134.
} 
anak sangat tergantung pengaruh dari luar yang datang. Teori konvergensi menyatakan bahwa pertumbuhan dan perkembangan manusia tergantung pada dua faktor: yaitu bakat atau pembawaan dan lingkungan atau sekolah. Teori konvergensi mengakui bahwa manusia lahir telah membawa bakat atau potensi-potensi dasar yang dapat dikembangkan. Proses pengembangan sangat tergantung pada lingkungan masyarakat dan sekolah. Kedua, Proses perkembangan sosial anak atau sebagai makhluk sosial yang berkepribadian dipengaruhi oleh banyak faktor, baik faktor internal (yang berasal dari dalam diri anak) maupun faktor eksternal (yang berasal dari luar diri anak). Ada lima faktor yang menjadi dasar perkembangan kepribadian anak, yaitu sifat dasar, lingkungan pre-natal, perbedaan individual, lingkungan dan motivasi.

\section{Rekomendasi}

Abu Ahmadi. 2016. Sosiologi Pendidikan. Surabaya: Bina Ilmu.

Ahmad, Zaenal Abidin. 2015. Konsep Negara Bermoral menurut al-Ghozali. Jakarta: Bulan Bintang.

Asrori. 2020. Psikologi Pendidikan Pendekatan Multidisipliner. Purwokerto: Pena Persada.

Langgulung, Hasan. 2006. Manusia dan Pendidikan. Jakarta: Pustaka al-Husna.

Moleong, Lexy J. 2014. Metodologi Penelitian Kualitatif. Bandung: Remaja Rosda Karya.

Soekanto, Soerjono. 2003. Sosiologi suatu Pengantar, Jakarta: Raja Grafindo Persada.

Tharaba, M. Fahim dan Moh. Padil. 2015. Sosiologi Pendidikan Islam, Malang: Dream Litera.

Veger, Karl. 2017. Pengantar Sosiologi. Jakarta: Grafindo.

Vembriarto (2010), Sosiologi Pendidikan, Yogyakarta: Gunung Agung. 